UDC 005.3:061.2

\title{
LEADERSHIP DEFICIT IN THE UKRAINIAN NON-PROFIT SECTOR
}

\section{ДЕФІЦИТ ЛІДЕРСТВА В УКРАЇНСЬКИХ НЕКОМЕРЦІЙНИХ ОРГАНІЗАЦІЯХ}

\author{
Kaitandzhian Hanna \\ PhD student, \\ Odesa I.I. Mechnikov National University \\ ORCID: https://orcid.org/0000-0002-3806-155X \\ Кайтанджян Ганна Самвелівна \\ Одеський Національний університет імені I.І. Мечникова
}

\begin{abstract}
In Ukraine, the non-profit sector plays an essential economic and community-building role. However, due to inadequate succession planning and training of future leaders, the third sector may face a leadership deficit. Given the pressure on non-profit organisations to become more business-like, and the fact that many non-profit organisations may be required to follow laws set by government funders, non-profit organisations may be able to recruit leaders from the for-profit and public sectors. The purpose of this research is to develop a vision of the third sector in Ukraine and shape leadership approaches in successful non-profits. The study served as an advance in understanding the relationship between a CEO's prior sector experience and their ability to lead non-profits. Interviews with non-profit CEOs in Odesa were conducted to obtain research results. This study finding showed that prior non-profit experience was more valuable than experience in the private or public sectors in enhancing NPO executives' abilities to lead. This study's findings may be exceptionally important for leaders of non-profit organisations, especially those who intend to enter this sector with no prior non-profit experience. Furthermore, this study provides evidence of the importance of prior experience in the non-profit sector upon executives' ability to lead NPOs.
\end{abstract}

Keyword: Non-profit organisations, leadership, deficit, job experience.

Стаття присвячена актуальним питанням управління некомерційними організаціями в Україні. В Україні неприбутковий сектор відіграє важливу економічну та громадську роль. Однак через недостатнє планування правонаступництва та підготовку майбутніх лідерів, третій сектор може зіткнутися з дефіцитом лідерства. 3 огляду на тиск на некомерційні організації, щоб вони стали більш схожими на організації приватного сектору, і той фракт, що багато некомерційних організацій зобов'язані дотримуватися законів, встановлених державними інститутами, некомерційні організації можуть бути в змозі набирати лідерів з приватного та державного секторів. Метою цього дослідження є розробка бачення третього сектору в Україні та фрормування лідерських підходів в успішних некомерційних організаціях. Дослідження послужило першім кроком у розумінні взаємозв'язку між попереднім досвідом керівників та їх здатністю керувати некомерційними організаціями. Для отримання результатів досліджень були проведені інтерв'ю з лідерами одеських некомерційних організацій різних типів, починаючи від місцевих громад, діаспор і закінчуючи міжнародними організаціями. Це дослідження виявило, що попередній некомерційний досвід був більш цінним, ніж досвід у приватному або державному секторах у підвищенні можливостей лідерів керувати НКО. Респонденті визнають, що попередній досвід роботи в інших секторах може бути корисним у розвитку здатності керувати некомерційною організацією. Однак респонденти також визнали, що вони можуть заповнити ті знання або досвід який в них бракує, відвідуючи тренінги. Це дослідження має цінність для некомерційного сектора з кількох причин. По-перше, результати дослідження дають можливість поглибити теоретичне розуміння лідерства в українських неприбуткових організаціях. Також дослідження має практичну цінність як для вчених, так і для менеджерів, а саме в питаннях планування правонаступництва, пошуку керівників для третього сектору. Більш того, результати дослідження користі для лідерів, які мають намір увійти в третій сектор без попереднього досвіду управління некомерційними організаціями.

Ключові слова: некомерційні організації, лідерство, дефіцит, попередній досвід.

Статья посвящена актуальным вопросам управления некоммерческими организациями Украины. В Украине некоммерческий сектор играет важную экономическую и общественную роль. Однако из-за недостаточного планирования правопреемства и подготовки будущих лидеров, третий сектор может столкнуться с дефрицитом лидерства. Учитывая давление на некоммерческие организации, чтобы они стали более похожи на 
организации частного сектора, и тот фракт, что многие некоммерческие организации обязаны соблюдать законы, установленные государственными институтами, некоммерческие организации могут быть в состоянии набирать лидеров из частного и государственного секторов. Цель этого исследования - разработка видения третьего сектора в Украине и фрормирование лидерских подходов в успешных некоммерческих организациях. Исследование послужило первым шагом в понимании взаимосвязи между опытом руководителей и их способностью руководить некоммерческими организациями. Для получения результатов исследований были проведены интервью с лидерами одесских некоммерческих организаций разных типов, начиная от местных общин, диаспор и заканчивая международными организациями. Это исследование показало, что предыдущий некоммерческий опыт был более ценным, чем опыт частного или государственного сектора в повышении возможностей лидеров руководить НКО. Респонденты признают, что опыт работы в других секторах может быть полезен в развитии способности управлять некоммерческой организацией. Однако респонденты также признали, что они могут заполнить недостающие в них знания или опыт, посещая тренинги. Это исследование имеет ценность для некоммерческого сектора по нескольким причинам. Во-первых, результаты исследования позволяют углубить теоретическое понимание лидерства в украинских неприбыльных организациях. Также исследование имеет практическую ценность как для ученых, так и менеджеров, а именно в вопросах планирования правопреемства, поиска руководителей для третьего сектора. Более того, результаты исследования пользы для лидеров, которые намерены войти в третий сектор без опыта управления некоммерческими организациями.

Ключевые слова: некоммерческие организации, лидерство, дефицит, предыдущий опыт.

In Ukraine, there are over 250000 non-profit organizations. In 2018, almost 26 million individuals were employed by public benefit non-profits such as colleges, social service agencies, and hospitals. As a result, the sector is a significant and increasing part of Ukraine's economy [18]. The size of the non-profit industry is expected to grow in the future due to demographic reasons such as an ageing population and a rise in the number of persons interested in volunteering. The third sector may not be able to offer the required number of leaders in the future, in part because some current employees may leave. For example, the majority of respondents in a study of designated "next-generation leaders" of non-profit organizations believed that a career in the sector might not meet their financial needs $[1$, p. 36]. Furthermore, the majority of non-profits did not have proper succession plans in place and/or did not believe there were suitable internal candidates to replace existing leaders, according to surveys of executive directors and board members [2, p. 3-20].

According to a 2007 poll, young non-profit professionals are reluctant to fill top-level positions in the sector since the executive director position is stressful and challenging to balance with their personal lives [11]. Such factors tend to commence a leadership crisis in the non-profit sector. According to the Bridgespan Group, the third sector will require 640,000 more senior managers over the next two decades [14, p. 26-35].

While data reveals that the non-profit sector has a leadership shortage, roughly $21 \%$ of people aged 50 to 70 who are not involved with the sector have expressed an interest in pursuing a career in organizations that serve the community [8]. These numbers show that non-profits may be able to recruit skilled leaders from outside the sector. The third sector is more flexible than ever and NPOs have to adjust and adopt such working patterns from the public sector to be able to comply with government contracts [9, p. 37-43] and apply private-sector risk management practices [4, p. 458-501], therefore, leaders with experience in the private or public sectors may be more likely to be hired by non-profits.

Although there may be some benefits to hiring leaders from other industries to run nonprofit organizations, the non-profit sector has its own set of obstacles. Non-profit organizations' mission statements, for example, tend to be more focused on addressing people's needs than for-profit organizations' mission statements [3, p. 141-163]. Furthermore, while leaders in the private sector are ultimately evaluated based on financial results, non-profit's scope can be ambiguous and heavily influenced by a variety of stakeholders goals; as a result, the criteria used to measure a leader's success are frequently ambiguous and certainly distinct from those used in the private sector [16, p. 69-84]. Using market-based concepts to manage non-profit organisations may result in lower-quality services and a decrease in social capital [5, p. 285-304]. As a result, hiring leaders from the profit-oriented sector to help a non-profit become more business-like may be a risky strategy. There is a need to assess the merits of this notion, and research is needed to determine the impact of expertise in other sectors on the capacity to lead non-profit organizations.

Moreover, some researchers conducted studies of MBA and MPA students at several universities who suggested individuals with experience in the private and public sectors had 
lower confidence regarding their abilities to lead non-profit organisations than they did in their abilities to lead organisations in other sectors [15, p. 668-688]. An additional study of twelve nonprofit leaders with substantial corporate experience found that changing from one sector to another was more difficult than the leaders expected due to differences in organizational culture, performance measurement, and revenue generation. Although the study suggested that leaders must be able to adapt when entering the non-profit sector, it did not examine how effectively the CEOs were at leading non-profits. As a result, more research is needed into the sector experience of non-profit leaders and the impact that past sector experience has on a CEO's abilities to lead non-profit organisations [10, p. 37-43].

To respond to this call, this article attempts to investigate Ukrainian non-profit executives' previous job experience and begins to discuss what, if any, impact sector experience has on a leader's capacity to lead non-profits. The findings have implications for non-profit researchers as well as non-profit organisations. The research was a crucial first step in determining the link between prior sector expertise and one's capacity to run Ukrainian non-profit organizations.

The study's findings imply that leadership experience in all three sectors (private, public and non-profit) has a positive impact on one's ability to lead non-profit organizations. Prior nonprofit sector experience, on the other hand, was assessed as having a higher positive impact on one's capacity to lead non-profit organizations than private or public sector experienced by respondents. Although the amount and breadth of experience in each sector may influence the impact of prior sector experience on one's ability to lead, this study's results suggest that previous experience leading non-profit organizations could provide leaders with specific experiences that may not occur in the private or public sectors.

Literature review. The third sector, as previously said, plays a major role in the Ukrainian economy and is an important component of society's well-being. The following are the most numerous non-profit organizations in Ukraine are diasporas, educational and cultural, health and social-oriented. Thus, the non-profit sector is critical to the development of communities and the well-being of society. Therefore, the assumption is that a shortage of qualified leaders in the nonprofit sector is imminent. As the third sector may have severe consequences for society [18].

Understandably, most nonprofits would consider it ideal if the next leader of their organisa- tion had experience within this sector. According to Teegarden, succession planning in non-profits most commonly envisions growing new leadership from within an organisation. Yet some scholars estimated that only about 30 to 40 per cent of senior non-profit management positions are filled by internal promotion (compared to 60 to 65 per cent in the business sector), and it is difficult to see how that approach can be adopted by the majority of very small non-profits. Consequently, this is one reason for the widespread belief in a leadership deficit [13, p. 78-90; 14, p. 26-35].

On the other hand, the for-profit and public sectors become more attractive for recruiting experienced managers to non-profits. Hence, non-profit organisations may decide to hire leaders with private sector experience if they are unable to find a leader with prior sector experience and/or if they are interested in embracing private sector business methods. Characteristics of the nonprofit sector such as a passion for mission, fluidity in the nonprofit landscape providing change and challenge, small and nimble organization size, and flat organizational structures would appear to be advantages in the non-profit sector's recruitment mission. Leete cites several studies that indicate the quality of work in the nonprofit sector was perceived as more varied and more challenging, provided more opportunities for skill development, and allowed more autonomy than for-profit jobs [7, p. 159-179]. However, while salary differentials may be less important to young workers within the relevant range of for-profit options, the Young Nonprofit Professionals Network reports that 82 per cent of their survey respondents cited low salary and wages as a likely reason for leaving the sector. Many of these respondents would be viewed as the next generation of nonprofit leaders: the majority were over age thirty-five, all had more than four years of experience in the nonprofit sector, and about half were already in director or manager positions [11].

They may also be interested in hiring executives within the public sector to ensure compliance with government funding criteria. It is worth mentioning that such employment methods may have implications for some distinguished goals that non-profits are aiming to achieve for society's well-being. According to one study, prior professional experience, both paid and voluntary increases the marketability of applicants for management positions and almost $18 \%$ of the respondents were hired from outside the non-profit sector [14, p. 26-35]. Unfortunately, few studies attempted to compare leaders who 
have expertise in different sectors, which could be useful in determining the efficacy of selecting leaders with experience in other sectors to lead non-profit organisations. As a result, more research into non-profit CEOs' prior experience is required. Unlike business entities, most NPOs are not unable to "create their own" supply of future leaders to meet the leadership shortage. Successful firms frequently spend a significant amount of money and time identifying and developing exceptional junior managers into leadership candidates. They understand that competence in talent development is a powerful kind of competitive advantage. However, most organizations (even those with higher budgets) are too small to offer meaningful professional development chances for next-generation leaders. They also can't afford to spend on the recruiting and human resources that such development necessitates, especially in an atmosphere where such investments are often seen as wasted overhead. As a result, NPOs are frequently forced to look for new senior executives outside of their sector [7, p. 159-179].

The following study questions were constructed to expand on the research on the professional experience of Ukrainian non-profit leaders and the impacts of prior sector experience on their ability to lead organisations within the third sectors:

1. In Odesa, what percentage of non-profit CEOs have only non-profit, only public, only private experience or in all of three sectors before working at their current organisation?

2. What impact does other sector expertise have on a CEO's ability to lead a non-profit organization? Do those who have worked in a certain sector assess their previous experience as a positive one or negative in terms of leading NPOs?
3. What percentage of leaders have a university degree, and what level of study have they obtained?

Design of the study. Due to a lack of prior research on non-profit executives' sector experience, a survey was created to answer the research questions.

The survey comprises 16 questions aimed at evaluating the leaders' socio-demographic profile, length of working in their current position, and title. In addition, respondents were asked to provide their thoughts on how previous experience in the non-profit, private, or public sectors influenced their abilities to lead a non-profit organisation. To answer research question two, the respondents were also asked to evaluate the current state of the third sector in Ukraine, the challenges they faced and what steps can be done to tackle their organisation's problems.

To commence the practical part of this study, it was essential to find the largest and most influential non-profit organisations in Odesa. Furthermore, several types of organizations, such as religious, social, cultural, national, human services, and so on, were chosen.

After completing the list of non-profit organizations, the next step was to make contact, it was necessary to call non-profit organisations, visit them, explain the study's goal, and inquire if an interview with the organization's executives could be arranged. And a total of twelve interviews were conducted.

Results. The first section of the questions was designed to clarify the survey's social demographic component. The majority of CEO positions are held by men $90 \%$. The bulk of those who responded had a Master's degree, while a few had a Bachelor's degree, $60 \%$ and $40 \%$, respectively.

Organisational Data and Personal Experience for Participants

Table 1

\begin{tabular}{|c|c|c|c|}
\hline $\begin{array}{l}\text { Respondent } \\
\text { A }\end{array}$ & Organisation's Type & Years in current position & Prior sector experience \\
\hline 1 & Diaspora & 13 & Private, Non-profit \\
\hline 2 & Diaspora & 15 & Private, Public \\
\hline 3 & Diaspora & 12 & Private, Public \\
\hline 4 & Diaspora & 10 & Private, Public \\
\hline 5 & Religious & 12 & Non-profit, \\
\hline 6 & Human Services & 2 & Non-profit, private \\
\hline 7 & Charitable Foundation & 3 & Private \\
\hline 8 & Social Organisation & 5 & Non-profit, public \\
\hline 9 & Social Organisation & 21 & Non-profit \\
\hline 10 & Social Organisation & 12 & Public \\
\hline
\end{tabular}


Table 1 shows that the majority of respondents had worked in the non-profit sector before joining their current organization. 20\% of respondents had only non-profit experience, $10 \%$ had only private sector experience, and $10 \%$ had only public sector experience. Before working at their present organization, the majority of respondents had experience in both the public and private sectors, with $20 \%$ having experience in both non-profit and private sectors and $10 \%$ having experience in both non-profit and public sectors.

Table 2 shows respondents answer to the following question: "What impact does sector experience have upon leading a non-profit organisation?"

Discussion of the research results and conclusion. The purpose of this study was to investigate how do CEOs of Ukrainian non-profit organisations perceive the impact of an experience, gained in the different sectors on their ability to lead non-profit organisations.

The study goes in line with prior studies on the career development of nonprofit CEOs that suggested that there is a wide range of sector experience among those who manage non-profit organisations [12, p. 696-716; 17, p. 103-133].

The results of the study suggest that leaders' experiences in the non-profit sector may be more helpful than experiences in the private and public sectors. However, experience in the nonprofit sector is not necessarily a prerequisite for leading non-profit organisations. While there are some clear differences in how non-profit organisations should be run compared to private and public sector organisations, at least some of the participants in the study suggested that the nuances required to effectively lead non-profit organisations can be learned on the job. Furthermore, this study suggests that prior experience in other sectors may be beneficial to some extent. For example, experience in the private sector may provide experience with business principles that may benefit sustainability and competitiveness and experience in the public sector may provide knowledge of public entities that is useful for organisations that receive their funding from the government. However, leaders from other sectors also need to understand those ways in which non-profit leadership is different and be willing and able to adapt.

Some scholars believe that although many leaders felt there are key business principles that can be learned in the private sector that have a positive impact upon the ability to lead non-profit organisations, the findings of this study suggest leadership should be exercised differently in the non-profit and private sectors $[6, p .471-486]$. And the results of this study go along with the previous statement. For instance, the majority of executives believe that prior private-sector experience helps them to lead nonprofit organizations. Responses of those who had never worked in the private sector were less optimistic in assessing the value of private sector experience for managing organisations in the non-profit sector. Nevertheless, the majority of those who had never worked in the private sector thought it would be beneficial.

To investigate further, the summary of each participant response is stated below.

Respondent \# 1, had extensive experience as a volunteer and as a board member with nonprofit organisations. In his opinion, basic business skills are important to leading a non-profit organisation. However, he argued that there are fundamental differences between non-profit and private organisations. For instance, non-profit leaders must be able to empower their followers and imply interest in their followers' well-being.

Respondent \# 2 believed that non-profit leadership experience is more helpful than experience

The Participants' Perceptions Regarding Impact of Sector Experience

Table 2 on Leading a Non-profit Organisation

\begin{tabular}{|c|c|c|c|}
\hline \multirow{2}{*}{$\begin{array}{c}\text { Respondent } \\
\#\end{array}$} & \multicolumn{3}{|c|}{ Impact of Sector Experience upon leading a non-profit organisation } \\
\cline { 2 - 4 } & Non-profit & Private & Public \\
\hline 1 & Strong positive & Strong positive & Strong positive \\
\hline 2 & Strong positive & Some positive & Strong positive \\
\hline 3 & Strong positive & Strong positive & Strong positive \\
\hline 4 & Strong positive & Some positive & Strong positive \\
\hline 5 & Strong positive & Some negative & Some positive \\
\hline 6 & Strong positive & Strong positive & Some positive \\
\hline 7 & Strong positive & Strong positive & Neither positive nor negative \\
\hline 8 & Strong positive & Some positive & Strong positive \\
\hline 9 & Strong positive & Neither positive nor negative & Some positive \\
\hline
\end{tabular}


in the other sectors because of their social-driven and less profit-oriented mission. He also emphasised that non-profits should see other organisations more as partners than competitors.

Respondent \# 3 argued that both private and public experience can help to lead a non-profit, but NPOs leaders would benefit from non-profit management training.

Respondent \# 4 felt the non-profit experience would be more helpful for leading a non-profit organisation than experience in other sectors. But as a leader of the diaspora, his experience within the public sector helped him with fundraising campaigns.

Respondent \# 5 was ascertained that for an NPO leader experience within the third sector is vital and CEO's from for-profits cannot lead NPOs in the right direction, taking into account the organisations true mission.

Respondent \# 6 felt the relative difference in leadership experiences was largely personal. First, he was not in direct contact with the leadership at the corporation he worked at. Second, he felt the non-profit environment was more conducive to his personality than a larger corporate-style structure.

Respondent \# 7 believed that public sector experience was helpful because it gave insight into how government agencies function and how individuals who lead public organisations motivate employees.

For respondent \# 8, prior non-profit and public sector experience were more valuable than experience in the private sector. She learned from other leaders within the governmental sector, how to represent one's organisation and use networking tools.

Respondents \# 9 believed that experience within the non-profit sector plays a vital role in understanding the relationship between a leader and followers, especially, with volunteered staff. And that can make one a true leader who serves the community's best interest.

Respondent \# 10 believed that experience in the public sector made her realize that the third sector plays a vital role in citizens well-being and, therefore, she started working in non-profits.

Concluding, the study suggested that leaders value prior non-profit experience more valuable than experience in the private and/or public sectors in developing leadership skills for effective management of the non-profit sector. Participants acknowledge that prior experience in other sectors can be beneficial in cultivating one's ability to lead a non-profit organisation. However, respondents believed that, whatever experience they lacked in a certain area crucial to leading a non-profit organisation, they were often able to overcome it by attending training sessions, etc. It's also important to note that experience in a particular industry may provide even more knowledge of organisational context than experience in a non-profit organisation in a different industry.

Theoretical and practical implications of the study. This study contributes considerable input into the theoretical foundation of the third sector in Ukraine by investigating non-profits leaders' educational backgrounds, experience in all three sectors, their assessment of current challenges.

The non-profit sector faces a leadership deficit and may wish to hire executives from other sectors. And this study serves as a first step in understanding the relationship between a CEO's prior sector experience and their ability to lead non-profits in Ukraine and shape leadership approaches in successful non-profits thus, important insights can be gained. Moreover, the results of this study indicate the critical role prior experience can play in leaders' ability to manage organisations within the third sector. Another implication relates to the preparation of managers within non-profit organisations. The finding of this study suggests that educational programs should consider including training programmes for preparing managers for the non-profit sector. In particular, leadership practices, fund-raising campaigns in the non-profit sector. contributed considerable input into the theoretical foundation of the third sector and practical implications relating to the training of senior managers of Ukrainian non-profits.

Limitations. This research has limitations, just like any other study. The sample of this study was limited by non-profit leaders in Odesa. As a result, the study findings may not imply for all non-profit organisations in other regions. Even though results were tested for non-response bias, there is still a chance that the sample contained some bias.

Another limitation is that because the leaders are now in the non-profit sector, their assessments of the importance of prior non-profit experience may be influenced. Even though leaders of NPOs of different types were interviewed, ranging from local communities to international organisations, the leaders' evaluation of prior experience from other types of non-profits may differ.

Future research recommendations. Further research into the importance of prior sector expertise could be conducted in several ways. 
For instance, to investigate followers and board members assessment of the impact of prior sector experience on leaders' ability to manage NPOs.

As it was stated in the limitations part, there is a need to research other regions of Ukraine to gather more data for comparison of the results. Furthermore, non-profit organisations are not all the same, therefore, additional studies can provide insight into the factors that are specific for different nonprofit organizations, which may also impact the significance of the prior experience.

\section{REFERENCES:}

1. Cornelius M., Corvington P., Ruesga A. (2011) Ready to Lead? Next Generation Leaders Speak Out The Annie E. Casey Foundation. Institution: CompassPoint Nonprofit Services, p. 36.

2. Froelich, K., Mckee, G., \& Rathge, R. (2011) Succession Planning in Non-profit Organisations. Non-profit Management and Leadership, vol. 22(1), 3-20.

3. Frumkin, P. \& Andre-Clark, A. (2000) When Missions, Markets, and Politics Collide: Values and Strategy in the Non-profit Human Services. Non-profit and Volunteer Sector Quarterly, 29(1), 141-163.

4. Henrikson, L. S., Smith, S. R., \& Zimmer, A. (2012) At the Eve of Convergence? Transformations of Social Service Provision in Denmark, Germany, and the United States. Voluntas, 23, 458-501.

5. Johnson, J. L. (2009) The non-profit leadership deficit: A case for more optimism. Non-profit Management \& Leadership, 19(3), 285-304.

6. King. N. K. (2004) Social Capital and Nonprofit Leaders. Nonprofit Management \& Leadership, 14(4), 471-486.

7. Leete, L. (2006) "Work in the Nonprofit Sector." The Nonprofit Sector: A Research Handbook. (2nd ed.) New Haven, Conn.: Yale University Press, 159-179.

8. Civic Ventures (2005) MetLife Foundation/Civic Ventures New Face of Work Survey. S. Francisco: Civic Ventures, 21-30.

9. Scott, W. R. \& Meyer, J. W. (1991) The Organisation of Societal Sectors: Propositions and Early Evidence. In W. W. Powell, \& P. J. Dimaggio, The New Institutionalism in Organisational Analysis. Chicago: The University of Chicago Press, 108-140.

10. Silverman, L. \& Taliento, L. (2006) What Business Execs Don't Know - but Should - About Non-profits. Stanford Social Innovation Review; Summer, 37-43.

11. Solomon, J., and Sandahl, Y. (2007) Stepping Up or Stepping Out: A Report on the Readiness of Next Generation Nonprofit Leaders. Young Non-profit Professionals Network. Retrieved from: http://www.artsusa.org/pdf/ networks/emerging_leaders/news_networking/featured_articles/stepping_up.pdf

12. Suarez, D. F. (2009) Street Credentials and Management Backgrounds: Careers of Non-profit Executives in an Evolving Sector. Non-profit and Voluntary Sector Quarterly, 39, 696-716.

13. Teegarden, P. H., Hinden, D. R., \& Sturm, P. (2011) Non-profit Organisational Culture Guide: Revealing the Hidden Truths that Impact the Performance. S. Francisco, CA, USA: Josey Bass, 78-90.

14. Tierney, T. (2006) 'The leadership deficit', Stanford Social Innovation Review, 4(2): 26-35.

15. Tschirhart, M., Reed, K. K., Freeman, S. J., \& Anker, A. L. (2008) Is the Grass Greener? Sector Shifting and Choice of Sector by MPA and MBA Graduates. Non-profit and Voluntary Sector Quarterly, 37(4), 668-688.

16. Weisbrod, B. (1998) Institutional form and organisational behaviour. In W. Powell \& E. Clemens (Eds.), Private action and the public good (pp. 69-84). New Haven, CT: Yale University Press.

17. Word, J. \& Park, S. M. (2009) Working Across the Divide: Job Involvement in the Public and Non-profit Sectors. Review of Public Personnel Administration, 29(2), 103-133.

18. Reiestr neprybutkovykh orhanizatsii ta ustanov v elektronnomu kabineti platnyka. Pres-sluzhba Derzhavnoi fiskalnoi sluzhby Ukrainy. Retrieved from: http://sfs.gov.ua/media-tsentr/novini/268858.html 